\title{
7 \\ THE ROLE OF GASTRONOMIC TOURISM IN RURAL DEVELOPMENT
}

\author{
Bernadett Csurgó, Clare Hindley and Melanie Kay Smith
}

\section{Introduction}

This chapter analyses the role of gastronomic tourism in rural development using specific case studies from Hungary. Rural development could be defined as a process of improving and protecting the economic and social wellbeing of rural communities. Theories on rural development emphasize the role of local culture and heritage, such as food, crafts, folklore, visual arts, literary references, historical and prehistorical sites, landscapes and associated flora and fauna (Bessière 1998; Ray 1998, 2006; Marsden 2006; Kivitalo, Kumpulainen, and Soin 2015). Rural tourism can ideally contribute to socio-economic diversification, community development, and the enhancement of image. Food has always been an integral part of tourism, but its significance has increased in recent years, especially in a rural context where it can play an important role in rural tourism and appeals to visitors' desire for authenticity (Sims 2009). Frisvoll, Forbord, and Blekesaune's (2016) research makes a connection between local food consumption, rural heritage and a 'rural idyll'. However, these authors also argue that the significance that local food holds in the context of rural tourism is largely unknown due to a lack of empirical research. Although there have been some exceptions (Ray 1998; Miele and Murdoch 2002), there is considerable scope for exploring these issues further. The main question posed is whether gastronomic tourism is an attractive and diverse enough product to become a primary motivation for visitors, or whether it needs to be part of a broader range of products connected to other forms of rural tourism (e.g., agritourism). The empirical case studies in this chapter examine the role of gastronomy in rural and tourism development in Hungary.

\section{The relationship between food, heritage, and tourism}

Food, a vital component of human life, is considered to be an essential commodity as well as an integral part of social and cultural heritage (Cavicchi and Ciampi Stancova 2016). Timothy (2015) describes how food's role in heritage includes its reflection of the cultural norms and values of people, places, and times, as well as elucidating the realities of geography and place. He argues that cuisine is a crucial component of the living culture as well as the heritage of 
communities. Berno's (2015) study on tourism and food traditions shows that tourism can be used as a conduit to rejuvenate traditional foods. Baldacchino (2015) suggests that food serves cultural and political functions, even as an icon of identity (see also Lugosi 2012). Earlier theorists such as Ray (1998) used the example of local food and gastronomy in his culture economy theory to present constructions of rural identity. Ray's theory is especially important in regions wanting to restructure and diversify. Indeed, rural tourism and gastronomic experiences can be central to processes of rural restructuring where producers use tourism and food to diversify their product base (Frisvoll, Fordbord, and Blekesaune 2016).

Yeoman et al. (2015) suggest that tourism and gastronomic heritage are inseparable. Nevertheless, while some tourists just eat because they need to, for others, food or gastronomy (defined by Scarpato (2003:52) as "enjoyment of the very best in food") can become a major draw or even a primary motivator for a trip (Corigliano 2002; Henderson 2009; Lin 2009). "Food can form part of the social, cultural, economic and environmental history of destinations and form a marketing 'hook' to attract consumers" (Sloan, Legrand, and Hindley 2015: 305). In some cases, food has become a real tourist attraction and can play a central role in the visitor's experience (Smith and Costello 2009; López-Guzmán and Jesus 2011; Sotiriadis 2015). So-called 'gastronomic', 'culinary', 'cuisine' or 'gourmet' tourism has become increasingly popular and tourists are becoming more adventurous and open to new experiences (Henderson 2009). It can include the consumption, preparation, and presentation of food items, cuisines, and eating systems which are different from those of the tourist (Long 2010). Wantanee et al. (2015) use the example of cookery classes in Thailand for tourists as a way to both sustain and spread local food culture. It can also include food festivals, routes and trails.

Corigliano (2002) states that gastronomic tourism allows the visitors to have a taste of the regional culture and thus to enter into contact with its traditions and heritage, as well as with the present lifestyle. Eating local food is a way of 'tasting a destination' (Cavicchi and Ciampi Stancova 2016). Kim and Eves (2012) provide an analysis of tourists' motivation to consume local food, which includes cultural experience, excitement, sensory appeal, interpersonal relations, and health concerns. Tourists are often attracted to rural destinations because of the perceived tradition and authenticity of typical local products and the local community's lifestyle (Corigliano 2002).

Traditions and local authenticity of a destination represent something new to the traveler, which is different from their home environment and therefore highly attractive for most people (Kauppinen-Räisänen, Gummerus, and Lehtola 2013). This means that local culture is appreciated by tourists due to it sperceived authenticity. On the other hand, gastronomy can also contribute to the 'aestheticisation' of rural areas through food preparation and consumption processes in restaurants (Miele and Murdoch 2002). Moreover, from the destination marketers' point of view, local food and tradition help shape a destination identity and differentiate it from the competitors, as well as giving the local communities a sense of pride (Lin 2009; Kesimoğlu 2015).

\section{The role of gastronomy in rural and agritourism}

The role of rural areas in the tourism industry has started to change, as those areas are increasingly viewed as places for entertainment, leisure activities, and as an alternative to urban life (Bessière 1998). If it is developed well, tourism can protect the heritage of rural areas and contribute to economic growth and the wellbeing of local communities. 
Ideally, tourism should preserve and promote indigenous products, as well as supporting traditional farming and local culture in general (Montanari and Staniscia 2009; Haghiri and Okech 2011).

Several authors have argued that gastronomic tourism is a relatively small niche sector with unpredictable powers of attraction. Baldacchino (2015) questions naive expectations placed on food as a panacea for struggling rural communities. It appears, therefore, that food producers should integrate their products into a broader conceptualization of rural tourism (Sidali, Kastenholz, and Bianchi 2015). Galluzzo (2015) suggests that food, rural traditions, rural territories, and agritourism can be blended into an integrated tourism product. The coexistence and cooperation between agricultural and tourism sectors has resulted in the development of so-called 'agritourism' (also 'agrotourism' or 'farm tourism') (Katsoni and Dionysopoulou 2015; Favaretto 2016). Agritourism can be defined as a niche part of rural tourism which focuses not only on food and food production, but also on rural lifestyles, traditions and environmental features of landscape. It is closely connected to the idea of the 'rural idyll', which combines local food consumption and rural heritage (Frisvoll, Fordbord, and Blekesaune 2016). Visitors can stay in a farmhouse, taste local food and may participate in farming activities, as well as rural tourism activities such as biking, horse riding, trekking, etc. Their main motivations are likely to be contact with nature, enjoyment of the countryside, and a longing for romanticized notions of a 'rural idyll' as the perfect antidote to urban living (Bessière 1998; Frisvoll, Fordbord, and Blekesaune 2016). Che (2016:85) suggests that agritourism can satisfy peoples' need for a slower place of life in "idyllic heritage spaces". Agritourism offers a chance to enjoy a personalized and authentic experience, usually involving local food (Montanari and Staniscia 2009). As stated by Timothy (2015:9) "nostalgia for an agrarian ideal" can drive the desire to know more about the origins and sources of food.

Agritourism has been recognized as a potential differentiation strategy for many Destination Management Organizations (Sotiriadis 2015). There seems to be a consensus in the research on agritourism that it can be a very effective tool for rural development and strengthening a destination's image and local identity (Bessière 1998; Haghiri and Okech 2011; Klimek 2013, Yurtseven and Karakas 2013; Che 2016). As stated by Pring et al. (2015:310) "Food represents an emerging theme in destination marketing that is increasingly seen as a core element of a destination's product offering providing a degree of uniqueness and differentiation." However, there are still many organizational challenges, including lack of cooperation between stakeholders (Montanari and Staniscia 2009; Klimek 2013), and exclusion of local communities from decision making processes (Fong and Lo 2015).

\section{The role of gastronomic tourism in rural development in Hungary}

Rural tourism is regarded as the key driver for local development in Hungarian rural areas. Food and gastronomy in rural tourism services and attractions are a focal point in all regions; however, their roles and position in rural development is very different (Csurgó and Megyesi 2015). Below we present two Hungarian case studies highlighting the development of gastronomic tourism and the roles of gastronomy and food in tourism-based rural development. 


\section{Case study 7.1}

The Örség region in Hungary shows gastronomic tourism as a secondary, complementary element of successful rural tourism-based development. This region is one of Hungary's main domestic rural tourism destinations. It is very rich in natural and cultural heritage and almost the whole region is managed by the Örség National Park. It is a very popular tourism destination as well as a second home area for the urban middle and upper middle classes who demonstrate a strong demand for a rural 'idyll' and authenticity. In the 1980s, urban newcomers started to buy second homes or settle in the region, and they also provided authentic rural accommodation for tourists, mostly for urban visitors.

Örség National Park was founded in 2002 and became the main driver of rural tourism development. The National Park endeavors to involve the 'original' inhabitants and local producers in their tourism development initiatives. In recent years, local food and gastronomy have become more and more important in the sense of place and authenticity, largely driven by visitor demand. Local tourism entrepreneurs, and restaurant and guest house owners started to provide local food and traditional dishes, created relationships with local small-scale producers, and began using traditional recipes. The Örség National Park also initiated the revitalization of traditional food production and gastronomy as part of an ecologically and culturally sustainable development. Örség National Park has a local food product brand based on traditional and environmentally friendly methods and expertise. Interestingly, consumers do not value the brand system very highly and are mainly interested in local authenticity perceived through the relationships with local producers and places.

The most traditional local food is pumpkin oil which has the strongest so-called Örség label/ image. Recently, several other local food products including honey, mushrooms, marmalade, pretzels (ring-shaped bread rolls), and fruit brandy have played an increased role. Örség's perceived 'idyllic' landscape can be experienced and tasted through food and gastronomy provided in local restaurants, gift shops and other local tourism services such as festivals and study trails More and more open manufacturers and kitchens are in operation (e.g., pumpkin oil manufacturers, strudel kitchens, pretzel kitchens). Local events also increasingly involve and present local food and gastronomic traditions. Local food and gastronomy are interconnected with the landscape, strengthening and enhancing its image as a rural 'idyll'. Originally, rural tourism in the Örség region was not specifically gastronomic tourism; instead, it was mainly landscape-based. However, local food and gastronomy have become one of the major services of this region in response to the changing demands of tourists and the aims of the National Park. This case can be seen as a successful example of how tourist demand for authentic gastronomy in a rural tourism destination can lead to development opportunities for the region. 


\section{Case study 7.2}

This case study of the Derecske-Létavértes region show gastronomic tourism can play a central role in local rural development. The Derecske-Létavértes micro region is characterized as a suburbanized area (an agglomeration of the city of Debrecen). The region is famous for the cultivation of horseradish, which became a PDO (protected designations of origin) in 2006. The main area of horseradish production inside the micro region is in Létavertes town and its surrounding villages with the center in Bagamér, a village where the main horseradish producing company is located. Horseradish is the most characteristic and unique agricultural product of the region. Eighty per cent of Hungarian horseradish comes from here and it is also one of the largest areas of cultivation for horseradish in Europe.

One of the main horseradish-producing companies proposed including horseradish in local development, especially cultural heritage-based rural development. The main idea was to generate tourism activities through the tradition of horseradish. In 2002, a local civic association, the Horseradish Tourist Route Association was established with the participation of eight local governments, four horseradish producing firms and a local restaurant. The main objectives of the Association are to revitalize local cultural heritage and generate gastronomic tourism with the purpose of local development. A Horseradish Round Table was organized to negotiate roles and opportunities for horseradish in local development with the primary goal of developing gastronomic tourism. This involved revitalizing the horseradish-inspired local gastronomy by collecting old recipes and inviting local restaurants to provide horseradish-based dishes. They also published brochures to present the local horseradish culture and other aspects of the cultural heritage of the joint settlements. Every year, a Horseradish Day and a Horseradish Festival are organized as cultural events involving more and more settlements in the micro-region. A Local Heritage Museum was founded to present the traditional cultivation methods of horseradish and its related heritage. It is important to note that horseradish did not have a cultural meaning before the Association started its activities, it was only regarded as the main economic resource. The Association's main target group is tourists, but the initiative has not met its original goals. The region is almost unknown as a tourism destination and has not yet gained wider popularity beyond local and regional visitors. However, a local network has been created through the new cultural and symbolic redefinition of horseradish, which resulted in local community building. Meetings were organized to create a space where local people come together to share stories, create networks and learn from each other. Gastronomic tourism based on horseradish is developing very slowly, and its real success is yet to be seen, but initial negotiation and development processes of horseradish-based gastronomic tourism have resulted in a strong and successful place identity planning process, where the cultural meaning of local food has become the driving force for identity creation and community building.

\section{Discussion and conclusions}

The case studies of Hungary support previous arguments that gastronomy and local food alone are often not sufficient to create a rural tourism profile. It can be seen that gastronomy and local food can play very different roles in rural tourism and development. In the case of the Örség region, gastronomy is one of the major rural tourism services, but here the starting point of tourism development was the concept of a rural 'idyll' which was closely connected to the 
unique landscape. Gastronomy emerged as a complementary service to increase the success of tourism development in the region. In Derecske-Létavértes, the starting point was local food, and the main aim was to develop gastronomic tourism as a driver of local development. However, gastronomictourism has not yet succeeded. Nevertheless, the process resulted in successful local identity and community building. Other cases in Hungary such as Kalocsa, which is famous for paprika production (the foundation of Hungarian cuisine), did not manage to develop gastronomic tourism. Instead, tourists visit for cultural reasons (e.g., to visit the paprika museum or to admire and buy the paprika-inspired lace) and usually only for one day or a few hours (Smith and Jusztin 2014; Csurgó and Megyesi 2015; Csurgó 2016).

Although gastronomy and food are an important part of local cultural heritage and play a central role in creating a sense of place and identity, this is often not sufficient for tourism development which goes beyond local or regional visitation. On the other hand, unique local food traditions (e.g., the gastronomic heritage of peasantry) can help to transmit the notion of a rural 'idyll' which is inextricably linked to landscape. This can attract urban visitors in particular and may lead to the purchasing of second homes or even settlement. Re-populating and re-invigorating rural areas which have often become depleted for economic reasons is an important part of rural development. In addition, the contribution to a local sense of place and identity, as well as community building, may lead to increased attractiveness for tourists in the future.

\section{Acknowledgments}

Case studies are based on the cultural heritage and sustainable rural development (OTKA 108628) project supported by the Hungarian Scientific Research Fund and on the cultural heritage and rural social integration project supported by the European Union and the State of Hungary, co-financed by the European Social Fund in the framework of TÁMOP 4.2.4. A/211-1-2012-0001 'National Excellence Program'. The work of Bernadett Csurgó is supported by the Bolyai János Postdoctoral Scholarship of the Hungarian Academy of Sciences.

\section{References}

Baldacchino, G. (2015). 'Feeding the rural tourism strategy? Food and notions of place and identity', Scandinavian Journal of Hospitality and Tourism, 15(1-2): 223-238.

Berno, T. (2015). 'Tourism, food traditions and supporting communities in Samoa' In Sloan, P., Legrand, W., and Hindley, C. (eds.), The Routledge Handbook of Sustainable Food and Gastronomy (pp.338347). London: Routledge.

Bessière, J. (1998). 'Local development and heritage: traditional food and cuisine as tourist attractions in rural areas', Sociologia Ruralis, 38(1): 21-34.

Cavicchi, A., Ciampi Stancova, K. (2016). Food and gastronomy as elements of regional innovation strategies. Spain: European Commission, Joint Research Centre, Institute for Prospective Technological Studies.

Che, D. (2016). 'Agricultural heritage, agritourism and rural livelihoods'. In Timothy, D.J. (ed.), Heritage Cuisines: Traditions, Identities and Tourism (pp.77-87). London: Routledge.

Corigliano, M.A. (2002). 'The route to quality: Italian gastronomy networks in operation'. In Hjalager, A.-M. and Richards, G. (eds.), Tourism and Gastronomy (pp.166-185), London: Routledge.

Csurgó, B. (2016). 'Nostalgia for the rural: Cultural heritage based tourism and community building in rural Hungary'. In Amoêda, R., Líra, S., and Pinheiro, C. (eds.), Proceedings of Heritage 2016 5th Intermational Conference on Heritage and Sustainable Development (pp. 1583-1592). Barcelos, Portugal: Green Lines.

Csurgó, B. and Megyesi, B. (2015). 'Local food production and local identity: interdependency of development tools and results', socio.hu, 5(Spec), 167-182. 
Favaretto, V. (2016). Sustainable Gastronomy as a Means to Strengthen Destination Image: The Example of the 'Agriturismi' in the Veneto Region. Bachelor Thesis., IUBH International University of Applied Sciences, Bad Honnef.

Fong, S.-F. and Lo, M.-C. (2015). 'Community involvement and sustainable rural tourism development: perspectives from the local communities', European Journal of Tourism Research, 11: 125-146.

Frisvoll, S., Forbord, M., and Blekesaune, A. (2016). 'An empirical investigation of tourists' consumption of local food in rural tourism', Scandinavian Journal of Hospitality and Tourism, 16(1): 76-93.

Galluzzo, N. (2015). 'Relationships between agritourism and certified quality food in Italian rural areas', Romanian Review of Regional Studies, 11(1): 77-88.

Haghiri, M. and Okech, R.N. (2011). 'The role of the agritourism management in developing the economy of rural regions', Tourism \& Management Studies, (1): 99-105.

Henderson, J.C. (2009). 'Food tourism reviewed', British Food Journal, 111(4): 317-326.

Katsoni, V. and Dionysopoulou, P. (2015). 'Agritourism marketing distribution strategy and typology investigation. The case of Arcadia', Tourismos: Multidisciplinary Journal of Tourism, 10(2): 131-152.

Kauppinen-Räisänen, H., Gummerus, J., and Lehtola, K. (2013). 'Remembered eating experiences described by the self, place, food, context and time', British Food Journal, 115(5): 666-685.

Kesimoğlu, A. (2015). 'A reconceptualization of gastronomy as relational and reflexive', Hospitality \& Society, 5(1): 71-91.

Kim, Y.G. and Eves, A. (2012). 'Construction and validation of a scale to measure tourist motivation to consume local food', Tourism Management, 33(6): 1458-1467.

Kivitalo, M., Kumpulainen, K., and Soini, K. (2015). 'Exploring culture and sustainability in rural Finland', in Dessein, J., Battaglinu, E. and Horlings, L., (eds.), Cultural Sustainability and Regional Development: Theories and practices of territorialisation, New York, NY: Routledge .

Klimek, K. (2013). 'Destination management organizations and their shift to sustainable tourism development', European Journal of Tourism, Hospitality and Recreation, 4(2): 27-47.

Lin, Y.-C. (2009). 'Linking local and culinary cuisines with destination branding'. In Cai, L.A., Gartner, W.C. and Munar, A.M. (eds.), Tourism Branding: Communities in Action, Bridging Tourism Theory and Practice (pp.105-118). Bingley, U.K.: Emerald Group Publishing Limited.

Long, L.M. (ed.) (2010). Culinary Tourism, Lexington, KY: University Press of Kentucky.

López-Guzmán, T. and Jesus, M.M. (2011) 'Turismo, cultura y gastronomía. Una aproximación a las rutas culinarias', Tourism \& Management Studies, 1: 916-922.

Lugosi, P. (2012). 'Food, drink and identity'. In Sloan, D. (ed.), Food and Drink: The Cultural Context (pp.20-50). Oxford: Goodfellow Publishers Limited .

Marsden, T. (2006). 'The road towards sustainable rural development: issues of theory, policy and practice in a European context'. In Cloke, P., Marsden, T., and Mooney, P. (eds.), Handbook of Rural Studies (pp.201-212). Thousand Oaks, CA: SAGE.

Miele, M. and Murdoch, J. (2002). 'The practical aesthetics of traditional cuisines: slow food in Tuscany', Sociologia Ruralis, 42(4): 312-328.

Montanari, A. and Staniscia, B. (2009). 'Culinary tourism as a tool for regional re-equilibrium', European Planning Studies, 17(10): 1463-1483.

Pring, M., Beer, S., Hartwell, H., and Bray, J. (2015). 'Local foods: marketing and the destination'. In Sloan, P., Legrand, W., and Hindley, C., eds., The Routledge Handbook of Sustainable Food and Gastronomy (pp.307-314), New York, NY: Routledge.

Ray, C. (1998). 'Culture, intellectual property and territorial rural development', Sociologia Ruralis, 38(1): 3-20.

Ray, C. (2006). 'Neo-endogenous rural development in the EU'. In Cloke, P., Marsden, T., and Mooney, P. (eds.), Handbook of Rural Studies (pp.278-291). Thousand Oaks, CA: SAGE.

Scarpato, R. (2003). 'Gastronomy as a tourist product: the perspective of gastronomy studies'. In Hjalager, A.-M. and Richards, G. (eds.), Tourism and Gastronomy (pp.51-70). New York, NY: Routledge.

Sidali, K.L., Kastenholz, E., and Bianchi, R. (2015). 'Food tourism, niche markets and products in rural tourism: combining the intimacy model and the experience economy as a rural development strategy', Journal of Sustainable Tourism, 23(8-9): 1179-1197.

Sims, R. (2009). 'Food, place and authenticity: local food and the sustainable tourism experience', Journal of Sustainable Tourism, 17(3): 321-336.

Sloan, P., Legrand, W., and Hindley, C. (2015). The Routledge Handbook of Sustainable Food and Gastronomy. New York, NY: Routledge. 
Smith, M.K. and Jusztin, M. (2014). 'Paprika: the spice of life in Hungary'. In Jolliffe, L. (ed.), Spices and Tourism: Destinations, Attractions and Cuisines (pp.53-71). Bristol: Channel View Publications.

Smith, S. and Costello, C. (2009). 'Segmenting visitors to a culinary event: motivations, travel behavior, and expenditures', Journal of Hospitality Marketing \& Management, 18(1): 44-67.

Sotiriadis, M.D. (2015). 'Culinary tourism assets and events: suggesting a strategic planning tool', International Journal of Contemporary Hospitality Management, 27(6): 1214-1232.

Timothy, D.J. (2015). Heritage Cuisines: Traditions, Identities and Tourism. London: Routledge.

Wantanee, S., Rodrigues, N.I., Ho, W., Luo, X.Y., Lam, I.C., and Chan, W.S. (2015) 'Sustaining and spreading local food culture through cooking classes'. In Sloan, P., Legrand, W., and Hindley, C. (eds.), The Routledge Handbook of Sustainable Food and Gastronomy (pp.86-95). New York, NY: Routledge.

Yeoman, I., McMahon-Beattie, U., Fields, K., Albrecht, J., and Meethan, K. (eds.) (2015). The Future of Food Tourism: Foodies, Experiences, Exclusivity, Visions and Political Capital. Bristol: Channel View Publications.

Yurtseven, H.R. and Karakas, N. (2013). 'Creating a sustainable gastronomic destination: the case of Cittaslow Gokceada - Turkey', American International Journal of Contemporary Research, 3(3): 91-100. 